\title{
Resureksi Bawang Goreng Produk Unggulan Sumberdadap Tulungagung di Tengah Pandemi
}

\author{
Figur Prayogo*, Yudha Nurdian \\ Program Studi Agroteknologi Fakultas Pertanian \\ Universitas Jember \\ *E-mail : figurprayogo123@gmail.com \\ DOI: https://doi.org/10.21107/pangabdhi.v6i2.8278 \\ Naskah diterima 28 Agustus 2020, Revisi 3 September 2020, Terbit 29 Oktober 2020
}

\begin{abstract}
Abstrak
Pandemi Covid-19 ini tidak hanya dirasakan oleh masyarakat perkotaan saja, bahkan masyarakat desapun juga ikut menjadi korban keganasan virus ini, terlebih dari segi ekonomi yang tidak bisa lagi seperti ketika keadaan normal. Seperti pada masyarakat di Desa Sumberdadap, Kecamatan Pucanglaban, Kabupaten Tulungagung yang mayoritas penduduknya berprofesi sebagai petani. Petani di Desa Sumberdadap banyak yang menanam tanaman bawang merah. Kegiatan distribusi yang terhambat, daya simpan bawang merah yang tebatas dan juga harga bawang merah yang bisa anjlok kapan saja menjadi masalah utama. Inovasi produk bawang merah menjadi bawang merah goreng "BAGORIN" diharapakan bisa menjadi solusi permasalahan tersebut, penjulan dan promosi melalui sosial media "Facebook" dan "Instagram dan juga marketplace online "Shopee" dirasa dapat membantu mengembalikan ekonomi masyarakat di Desa Sumberdadap terdampak Covid-19 ini.
\end{abstract}

Kata Kunci: virus, ekonomi, petani, bawang merah, Sumberdadap

\begin{abstract}
The Covid-19 pandemic is not only felt by the community, even rural people have also become victims of this virus, especially from an economic point of view that can no longer be like when conditions were normal. For example, the community in Sumberdadap Village, Pucanglaban District, Tulungagung Regency, whose residents work as farmers. Many farmers in Sumberdadap village plant shallot plants. Obstructed distribution activities, limited storage capacity of shallots and also the price of shallots which can drop at any time are the main problems. It is hoped that the innovation of shallot products into "BAGORIN" fried shallots can be a solution to this problem, sales and promotion through social media "Facebook" and "Instagram and also the online marketplace" Shopee "are deemed to be able to help restore the economy of the community in Sumberdadap Village affected by Covid-19.
\end{abstract}

Key Words : virus, economy, farmers, shallot, Sumberdadap

\section{PENDAHULUAN}

Virus COVID19 (Corona Virus Disease 2019) merupakan virus yang dapat mengakibatkan penyakit dari ringan, sedang, hingga berat. Virus ini cukup menjadi perhatian dunia, karena dengan adanya pandemi virus Covid-19 ini, banyak sektor mengalami kebobrokan, mulai dari kesehatan, pendidikan, ekonomi dan lain-lain (Yuliana, 2020). Kebobrokan ini mengakibatkan munculnya aturan-aturan baru secara mendadak, seperti pembatasan kerja diluar rumah, dan mengurangi aktivitas diluar rumah lainnya. Karena penyebaran virus Covid-19 ini yang cukup cepat, aktivitas kantor dan pekerjaan diluar rumah lainnya berkurang, sehingga jual beli secara offlinepun terpaksa harus dibatasi.
Karena hal ini, banyak sekali masyarakat yang dikeluarkan dari pekerjaannya atau dipecat.

Siapa yang menyangka, dampak dari pandemi Covid-19 ini ternyata tidak hanya dirasakan oleh masyarakat perkotaan saja, bahkan masyarakat desapun juga menjadi korban keganasan virus ini, kestabilan ekonomi yang tidak bisa lagi seperti ketika keadaan normal. Seperti pada masyarakat di Desa Sumberdadap, Kecamatan Pucanglaban, Kabupaten Tulungagung yang mana penduduknya lebih banyak berprofesi sebagai petani. Petani di Desa Sumberdadap banyak yang menanam tanaman bawang merah, karena memang kondisi wilayahnya yang cukup mendukung seperti tanah dan ketersediaan air yang cukup. Petani bawang merah mengalami 
penurunan penghasilan yang cukup besar karena pendistribusian hasil panen yang tidak bisa dilakukan diluar kota secara sembarangan karena harus menaati peraturan pemerintah pada saat pandemi yaitu kerja dirumah. Bawang merah yang tidak segera sampai ke tangan konsumen tentunya akan mengalami penurunan kualitas, karena sudah pasti bawang merah memiliki umur daya simpan.

Inovasi terhadap bawang merah dilakukan dengan tujuan yang utama yaitu menambah daya simpan produk dan juga meningkatkan nilai jual produk. Bawang merah yang diolah menjadi bawang merah goreng atau biasa disebut bagor ini, akan memiliki daya simpan yang lebih lama, selain itu pasar bawang merah juga cukup banyak baik disekitar maupun diluar kota, karena berupa produk olahan dengan kemasan yang tidak terlalu besar, menjadikan produk bagor ini dapat dijual secara online dengan memanfaatkan jasa ekspedisi pengiriman yang tersedia di sekitar, sehingga pendistribusiannya juga dapat melalui jasa ekspedisi setempat tanpa harus keluar kota sendiri untuk mengirim produk bagor.

Produk yang dijual secara online melalui media sosial dan market place online ini diharapkan mampu membidik pasar lebih luas, kegiatan promosi baik yang berbayar maupun gratis dengan cara membagikan foto produk melalui akun personal, sehingga teman sosial media akan dapat menemukan produk dengan cukup mudah.

\section{METODE}

Kegiatan KKN Back to Village Universitas Jember ini dilakukan pada tanggal 1 Juli 2020 sampai 14 Agustus 2020 di Desa Sumberdadap, Kabupaten Tulungagung. Metode pelaksanaan yang digunakan untuk mencapai tujuan yang diharapkan program KKN Back to Village yaitu Inovasi bawang merah menjadi produk bawang goreng dan dijual secara online melalui sosial media Facebook, Instagram dan marketplace online Shopee.

Kegiatan dilakukan sesuai protokol kesehatan, seperti menggunakan masker dan menjaga jarak aman 1 meter dengan oranglain, dan tidak lupa untuk sering mencuci tangan. Kegiatan diawali dengan survei ke lokasi yaitu di Desa Sumberdadap, dan juga mencari data yang dibutuhkan. Kegiatan ini bertujuan untuk menangkap permasalahan yang ada disekitar Desa Sumberdadap yang terdampak Covid-19 ini dari segi ekonomi setempat.

Tahap selanjutnya yaitu pelaksanaan, kegiatan KKN UNEJ Back to Village ini dilaksankan di Desa Sumberdadap dengan sasaran petani bawang merah dan dilakukan secara individu, pada tahap ini, mahasiswa membuat kegiatan pendampingan ke masyarakat sasaran yang mana diawali dengan pendampingan untuk membuat produk bawang goreng dan setelah itu baru pengemasan, dan dilanjutkan dengan pengenalan online market place Shopee serta cara berjualan online dan menentukan target pasar, baru yang terakhir penjualan dan promosi melalui akun sosial media seperti Facebook dan Instagram. Untuk jelasnya kegiatan selama 45 hari di Desa Sumberdadap bisa dilihat pada gambar dibawah ini:

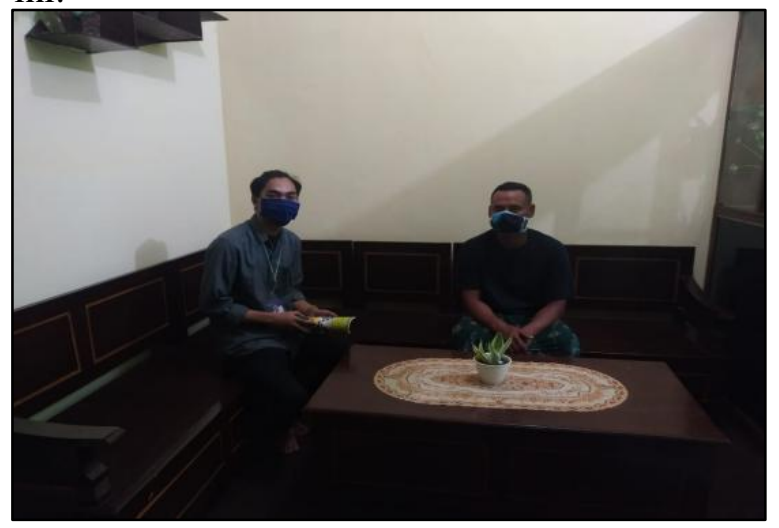

Gambar 1. Diskusi dengan Masyarakat Sasaran

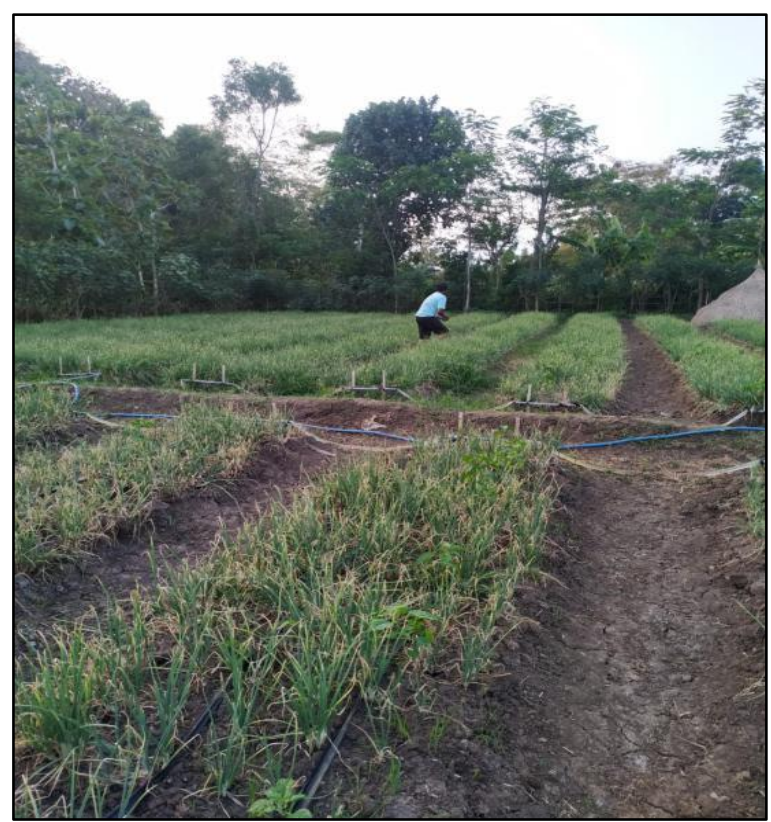

Gambar 2. Pemanenan Bawang Mera

\section{HASIL DAN PEMBAHASAN}

Mahasiswa KKN UNEJ Back to Village di Desa Sumberdadap melakukan kegiatan KKN 
selama 45 hari secara individu dengan mungusung tema Kewirausahaan dan setelah melihat kondisi masyarkat sekitar yang terdampak Covid-19 ini, maka fokus permasalahan akan diarahkan ke kegiatan yang dapat menunjang ekonomi masyarakat sekitar seperti pengolahan produk bawang merah menjadi bawang merah goreng dan dibranding dengan nama "BAGORIN". Bawang merah diambil langsung dari petani setempat yaitu di Desa Sumberdadap, yang mana mayoritas penduduknya bekerja sebagai petani dan cukup banyak yang menanam komoditas bawang merah.

Instagram merupakan sebuah aplikasi berbagi gambar yang dengan seiring berjalannya waktu telah berkembang menjadi salah satu alat pemasaran yang paling efektif. Kekuatan visual dianggap lebih mempunyai daya tarik untuk membawa konsumen melakukan konversi dibandingkan dengan cara lainnya (Untari dan Fajariana, 2018).

Facebook merupakan sosial media online yang dimana pengguna dapat bebas mengunggah gambar atau video atau konten yang lain bahkan sampai dengan penjualan. Fasilitas Iklan berbayar dengan detail targeting yang spesifik menjadi keunggulan beriklan menggunakan facebook dibanding media konvensional, besar kecilnya biaya iklan serta keahlian admin juga pembuat konten berpengaruh pada sebaran publikasi pesan dan interaksi yang terjalin pada suatu kampanye iklan tersebut. Strategi marketing di eksekusi pada akun facebook fanpage, personal dan grup (Asse, 2018). Penggunaan iklan ini tentunya kaan sangat efektif apabila tatget pasar yang dibidik tepat sasaran.

Shopee adalah salah satu situs belanja online pendatang baru, jika dibandingkan dengan situs belanja online lainnya. Shopee hadir dengan metode terintegrasi dengan dukungan logistik yang memiliki metode pembayaran yang aman dan nyaman. Sehingga membuat belanja online menjadi mudah, baik bagi penjual maupun pembeli. Strategi pemasaran melalui bisnis media online kenyatannya cukup sulit dalam menembus pasar di Indonesia. Hal ini disebabkan karena begitu banyak perbedaan konsumen di Indonesia mulai dari cara berbelanja, mengapresiasikan suatu produk, promosi penjualan, keadaan ekonomi, perbedaan budaya dan perkembangan teknologi menjadi tantangan (Fauziah, 2020). Namun tetap saja dengan penjualan secara online masyarakat akan sangat terbantu. Selain itu, penjualan secara online juga sangat cocok dan tepat ketika dialkukan di masa pandemi Covid-19 seperti saat sekarang ini.

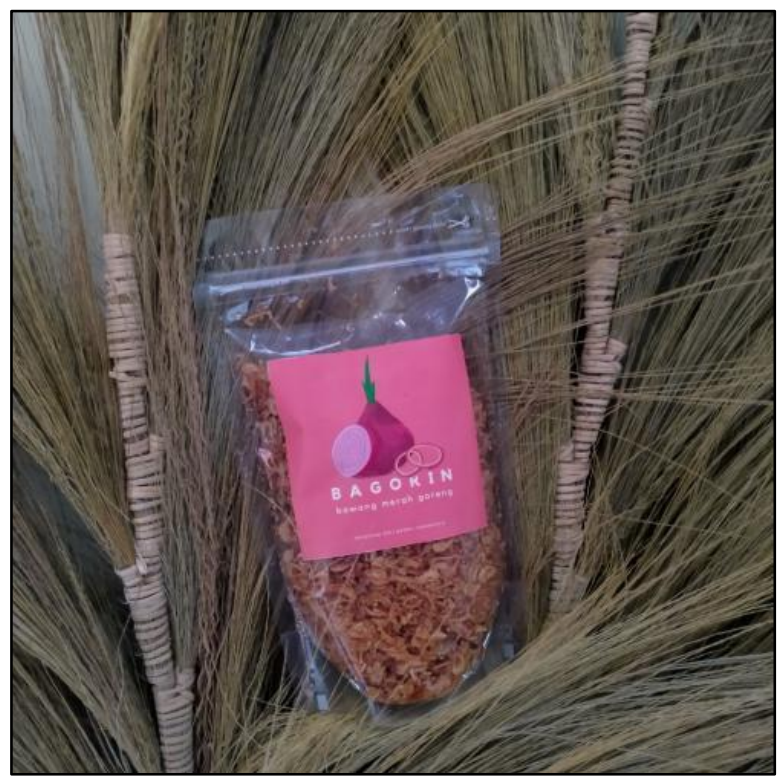

Gambar 3. Pembuatan Logo Produk Bawang Goreng

Jumlah pemilik toko online meningkat tajam faktor yang mempengaruhi pembelian produk onlineshop terutama kepercayaan (trust) dan selanjutnya akan menghasilkan loyalitas (loyalty) pelanggan online. Agar pelaku bisnis dapat berhasil maka yang utama dilakukan adalah membangun trust dan loyalitas pada benak pelanggan untuk menunjang bisnis onlineshop tersebut. Promosi dilakukan untuk berkomunikasi dan mempengaruhi pelanggan agar dapat menerima produk yang dihasilkan. Pemasar dapat merancang promosi dengan berbagai cara, seperti periklanan, promosi penjualan, publisitas penjualan individu dan kemasan yang menarik, di Intagram dan Facebook sendiri menyediakan fitur iklan dengan berbayar (Kurniawan 2017). Untuk budget yang minim, bisa melakukan iklan atau promosi melalui akun pribadi, teman maupun kenalan yang lain untuk membantu dalam promosi baik melalui postongan di feed maupun di instastory Instagram.

Jadi sejatinya mau menggunakan media online apapun, asalkan tepat sasaran, maka produk akan dapat laku dipasar online. Iklan yang berbayarpun dapat diakali dengan beberapa cara seperti promosi melalui akun pribadi dan teman, sehingga penyebarannya akan luas. Cukup banyak stategi yang dapat dilakukan dengan penjualan secara online. Maka dari itu 
tidak cukup apabila penjelasan kemasyarakat di Desa Sumberdadap yang terdampak ini hanya dengan teori tanpa praktik, maka dari itu terjun langsung sangat diperlukan agar masyarakat dapat merasakan pengalaman langsung jual beli secara online.

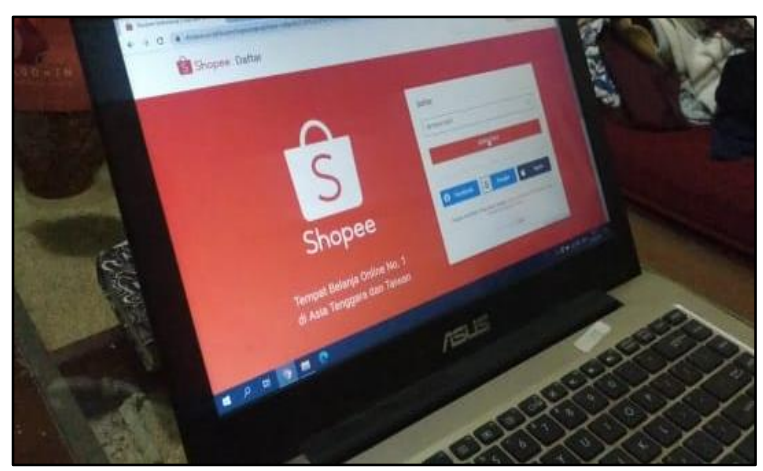

Gambar 4. Pengenalan dan Pendampingan Terkait Penjualan di Market Place Online Shopee

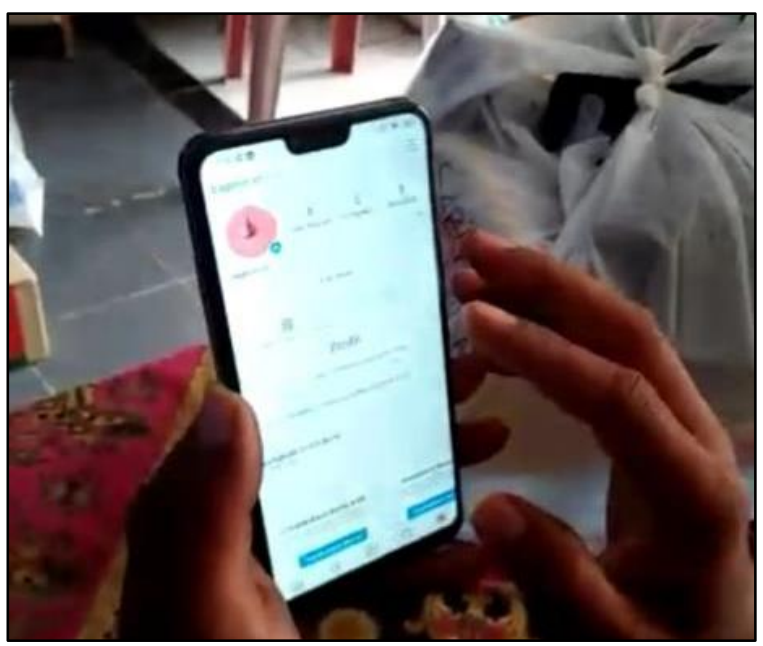

Gambar 5. Pendampingan Sasaran dalam

Penjualan dan Promosi Produk Bagorin Melalui Sosial Media Online Facebook dan Instagram

Kegiatan ini tentunya harus ada pendampingan langsung dari mahasiswa KKN UNEJ Back to Village di Desa Sumberdadap, yang mana pendampingan ini dilakukan dengan mengadakan sosialisasi langsung ke masyarakat setempat, adapun sosialisasi kegiatan yang sudah direncanakan antara lain yaitu:

1) Pengenalan online marketplace shopee ke masyarakat.

2) Pendampingan masyarakat dalam penjualan produk melalui sosial media.

3) Mengenal pasar dan target pasar dari produk bagorin.

4) Pendampingan masyarakat dalam promosi produk bagorin melalui media sosial.
Penjualan dan promosi secara online memang memiliki kekuatan yang cukup bagus dikala pandemi seperti sekarang ini, ditambah lagi akses internet dan keberadaan teknologi yang canggih sudah dapat ditemui dimana-mana, tidak hanya dikota melainkan di desapun sudah mendapatkan akses internet yang cukup cepat. Untuk distribusipun di Desa Sumberdadap juga sudah ada layanan ekspedisi keluar kota meskipun hanya beberapa saja seperti POS dan JNE tapi itupun sudah cukup. Meskipun teknologi sudah siap, SDM masyarakat di Desa Sumberdadap belumlah siap, masih banyak yang kurang mengenal jual beli secara online (Khoirudin dan Fahrullah, 2020). Kekurangan tersebut bisa diminimalisir dengan cara pengenalan dan pendampingan ke masyarakat agar bisa bertransaksi jual maupun beli secara online.

Hasil dari kegiatan KKN UNEJ Back To Village yang dilaksanakn selama 45 hari ini masyarakat sudah mulai muncul minat untuk berinovasi membuat produk dari hasil panennya sendiri maupun hasil panen masyarakat sekitar, dengan ini diharapakan dapat membuka peluang pekerjaan bagi masyarakat sekitar. Masyarakat di Desa Sumberdadap juga sudah mulai mengenal dan terus mempelajari penjualan dan promosi produk secara online sehingga akan sesuai yang diharapkan dari kegiatan ini yaitu, bermanfaat tidak hanya selama 45 hari, namun dapat terus berkelanjutan. Masyarakat desapun harus bisa mengikuti perkembangan teknologi yang semakin berkembang. Menggantikan peran penjualan secara offline, penjualan melalui media online atau secara online diharapkan mampu untuk menjadi solusi sempitnya pasar apabila hanya mengandalkan pasar offline, dengan menjual secara online pasar akan semakin luas sehinggan diharapkan dapat meningkatkan penjualan suatu produk (Wulandari, 2015).

\section{KESIMPULAN}

Pandemi Covid-19 memberikan dampak yang terasa secara ekonomi di Desa Sumberdadap, inovasi produk usaha tani dirasa bisa diramaikan untuk mengatasi resesi, produk inovasi pengolahan bawang merah menjadi bawang merah goreng "BAGORIN" juga untuk meningkatkan daya simpan dan nilai jual produk. Penjualan melalui sosial media online (Facebook dan Instagram) dan market place online (Shopee) diharapkan mampu menambah dan memperluas 
pasar, sehingga akan meningkatkan penjualan produk BAGORIN.

\section{UCAPAN TERIMA KASIH}

Terima kasih kepada masyarakat sasaran yang sudah meluangkan waktunya untuk menyukseskan kegiatan KKN UNEJ Back to Village bertema Kewirausahaan ini dengan senang hati. Terima kasih kepada LP2M yang telah menyelenggarakan KKN dengan cukup baik dikala pandemi Covid-19 seperti sekarang.

\section{DAFTAR PUSTAKA}

Asse R. A. A. 2018. Strategi Pemasaran Online (Studi Kasus Facebook Marketing Warung Bakso Mas Cingkrank Di Makassar). Jurnal Komunikasi KAREBA. Vol 7 (2). 219-231 pp.

Fauziah. 2020. Strategi Komunikasi Bisnis Online Shop "Shoppe" Dalam Meningkatkan Penjualan. Jurnal Abiwara. Vol 1 (2). 45-53 pp.

Khoirudin M. H. dan Fahrullah A. 2020. Implementasi Strategi Pemasaran Berbasis Internet Marketing Untuk Meningkatkan
Pendapatan Pada Laznas Nurul Hayat Surabaya. Jurnal Ekonomika dan Bisnis Islam. Vol 3 (1). 71-78 pp.

Kurniawan, P. 2017. Pemanfaatan Media Sosial Instagram Sebagai Komunikasi Pemasaran Modern Pada Batik Burneh. Kompetensi. Vol 11 (2). 217-225 pp.

Untari D. dan Fajariana D.E. 2018. Strategi Pemasaran Melalui Media Sosial Instagram (Studi Deskriptif Pada Akun @Subur_Batik). Widya Cipta. Vol 2 (2). 271-278 pp.

Wulandari D. A. 2015. Pengaruh Penjualan Online Terhadap Omzet Penjualan Butik Zieta Desa Sewulan Kec. Dagangan Kab. Madiun. Equilibrium. Vol 3 (2). 134-143 pp.

Yuliana. 2020. Corona Virus Deseases (Covid19); Sebuah Tinjauan Literatur. Wellness and Healthy Magazine. Vol 2 (1). 187-192 pp. 
74 Jurnal Pangabdhi 